\title{
The Complexity of the Caspian Basin
}

\author{
Koutsouradi Markella
}

PhD Candidate, Department of Shipping, Trade and Transport,

University of the Aegean, Greece

Karkazis John

Dean of the School of Business, University of the Aegean, Greece

Siousiouras Petros

Professor of Geopolitics and Maritime Transport,

Department of Shipping, Trade and Transport,

University of the Aegean, Greece

Chondrogianni Dionysia

PhD Candidate, Department of Shipping, Trade and Transport,

University of Aegean, Greece

Doi:10.19044/esj.2018.v14n26p159 URL:http://dx.doi.org/10.19044/esj.2018.v14n26p159

\begin{abstract}
The collapse of the Soviet Union and the emergence of newly independent States marked the uprising of a new era in the region of the Caspian Basin. Failing to reach a consensus regarding the legal nature of the Caspian, Russia, Turkmenistan, Iran, Azerbaijan, and Kazakhstan's policies have been characterized by a perpetual pursuit of establishing themselves as key-role agents in the region. The question about "Lake or Sea" is yet to be answered after many decades. This paper focuses on analyzing the significance of the Caspian Basin for the littoral States and how it determines their political agenda.
\end{abstract}

Keywords: Caspian, natural resources, legal status

\section{INTRODUCTION}

The Caspian Sea has been considered "a region of complexities" and has been characterized by a considerable heterogeneity in people, languages, and cultures (Gokay, 2001). The area in question has drawn a lot of attraction. Albeit, the cornerstone of its interest lies on the natural resources- especially oil reserves- situated on the Caspian basin. Having been regarded as a throughout-history oil producing region, the Caspian Sea tends to be an energy crossroad affecting the geopolitics of energy. 
To begin with, the Caspian Sea is regarded as one of the most essential geopolitical and geostrategical regions of the world. It is a body of water, located in northwest Asia and is surrounded by five littoral States, namely Azerbaijan, Iran, Kazakhstan, Russia, and Turkmenistan. Moreover, since it holds vast deposits of oil and gas resources, it is a vital supplier not only for Europe's energy demand but for Asian's markets too. According to US Energy Information Administration (henceforth EIA) in 2012, there were 292 trillion cubic feet (Tcf) of natural gas. However, it was estimated that $243 \mathrm{Tcf}$ of natural gas is yet to be discovered (EIA, 2013). It is of paramount importance to stress the fact that the majority of the offshore oil deposits are situated on the Northern part of the Caspian Sea, whereas most of the offshore natural gas reserves are situated on the Southern part (EIA, 2013). In addition to this estimation, the U.S Geological Survey (henceforth USGS) claims that the region holds 19.6 billion bbl of undiscovered crude oil (USGS, 2010). As the world's demand for oil and gas resources is foreseen to increase in the future and as energy consumption rises, the Caspian basin serves as a vital diversified energy source for many countries.

The figure below depicts the oil and gas reserves in the Caspian Sea. The reserves have been estimated in both onshore and offshore of the Caspian basin. It can be concluded, by numbers, that Kazakhstan is the major player in the region as it holds almost $65 \%$ of crude oil (31.2 billion bbl) and $36 \%$ of natural gas (104 Tcf). Russia is the second important claimant in the Caspian Sea as it holds $13 \%$ of crude (6.1 billion bbl) oil and 37\% of natural gas (109 Tcf offshore and onshore). Furthermore, this is followed by Azerbaijan, Turkmenistan, and Iran. The most interesting observation is that Iran, which is one of the most significant oil producers in the world, has less oil and gas reserves in the region. In the table below, it is depicted by the letter "s" which means that the value is too small to be shown (EIA, 2013). 


\begin{tabular}{|c|c|c|}
\hline Country & Crude oil and lease condensate (billion bbl) & Natural gas (Tcf) \\
\hline Azerbaijan & 8.5 & 51 \\
\hline Offshore Caspian & 6.8 & 46 \\
\hline Onshore Caspian & 1.7 & 5 \\
\hline Iran & 0.5 & 2 \\
\hline Offshore Caspian & 0.5 & 1 \\
\hline Onshore Caspian & (s) & 1 \\
\hline Kazakhstan & 31.2 & 104 \\
\hline Offshore Caspian & 15.7 & 36 \\
\hline Onshore Caspian & 15.5 & 68 \\
\hline Russia & 6.1 & 109 \\
\hline Offshore Caspian & 1.6 & 14 \\
\hline Onshore Caspian & 4.5 & 95 \\
\hline Turkmenistan & 1.9 & 19 \\
\hline Offshore Caspian & 1.1 & 9 \\
\hline Onshore Caspian & 0.8 & 10 \\
\hline Uzbekistan & (s) & 7 \\
\hline Offshore Caspian & 0 & 0 \\
\hline Onshore Caspian & (s) & 7 \\
\hline $\begin{array}{l}\text { TOTAL } \\
\text { CASPIAN }\end{array}$ & 48.2 & 292 \\
\hline Offshore Caspian & 19.6 & 106 \\
\hline Onshore Caspian & 28.6 & 186 \\
\hline
\end{tabular}

Figure 1. Source: U.S Energy Information Administration https://www.eia.gov/beta/international/regions-topics.cfm?RegionTopicID=CSR

As it was mentioned before, the Caspian Sea is a body of water which can be characterized either as a land - locked sea or a border lake. On the one hand, legal experts claim that the Caspian Sea is a land - locked sea or enclosed sea due to its salty water, especially in its southern part (Ganjaliyen, 2011-2012). However, this is attributed to the fact that the only exits towards the open seas and oceans are through the Russia's Volga River and the canals that connect it to the Black Sea, the Baltic Sea, and the Sea of Azov (Zimnitskaya \& Geldern, 2011). On the other hand, the majority of geologist claims that the Caspian Sea is a border lake (Shafiyev, 2001), which is particularly the world's largest lake (Ganjaliyen, 2011- 2012). Their classification as a border lake is due to the fact that the Caspian Sea is located on a basin, surrounded by five riparian States and, as it is not a part of the oceans, the only exit towards the open seas is through artificial canals. 
As it may be concluded by the aforementioned, the Caspian Sea falls into the category of border lakes. It should be stressed that other lakes- such as the Lake Titicaca - have been classified as border lakes as well. According to International Law, the legal status of border lakes is determined either after consensus establishment among the riparian States or under the regime of condominium (Pawletta, 2015). However, the Lake Titicaca - border lake divided between Bolivia and Peru - consists of the only border lake under the regime of condominium (Pawletta, 2015). According to "Preliminary Convention between Peru and Bolivia Concerning a Study of the Joint Utilization of the Waters of Lake Titicaca", it was stressed that "as regards the utilization of the waters of Lake Titicaca for industrial or other purposes, the two Governments declare that the said waters, being the joint and indivisible property of both, may be used only with the express agreement of the two parties" (Premilinary Convention, 1955).

Except for the legal status of the Caspian basin, it is also important that the attitude of the five littoral States should be analyzed.

\section{RUSSIA}

Russia is one of the world's leading natural resources' producers. As a lot of its economy depends on oil and gas production, Russia does not want to be cut off from every possible oil and gas vat. According to EIA, Russia's proved oil reserve were 80 billion barrels, in 2016, and are located majorly in West Siberia and in the Urals - Volga region, including the Caspian basin (EIA, 2016). Russia's desire to play a crucial role in the supply chain of gas and oil towards European and Asian markets made it take control or at least be a part of every potential natural resource's reservoir. This is the main reason why Russia changed its position, concerning the legal status of the Caspian Sea, several times throughout history.

To begin with, during the empire of the Union of Soviet Socialist Republics (henceforth USSR), the only countries that shared the Caspian basin were the USSR and the Persian empire. Between these countries were signed several treaties regarding the legal status of the Caspian Sea. The first one was the "Treaty of Friendship between Persia and the Russian Socialist Federal Soviet Republic", signed at Moscow on $26^{\text {th }}$ February 1921 (henceforth the 1921 Treaty). According to Article 1 of the 1921 Treaty, the Russian Republic stated that all the treaties, that both countries signed during the Tsarist Government "and crushed the rights of the Persian people", were not valid (Article 1, 1921). Moreover, the treaty claimed that both States would have equal rights in the Caspian Sea including the right of free navigation under their flag (Article 11, 1921). It is worth mentioning that despite the fact that this treaty does not regulate the legal status of the Caspian basin, as it did not mention the territorial sovereignty over it, it is of paramount importance in 
light of the fact that it is the first time that equal rights have been recognized for both States.

Furthermore, in 1940, both countries signed the "Treaty of Commerce and Navigation" (henceforth the 1940 treaty) which reaffirmed that only these countries should have rights on the Caspian Sea and all the third States were excluded and were restricted even from the right of innocent passage. Last but not least, both States claimed a 10 - mile zone among their coast only for fishing (Pawletta, 2007; Bahgat, 2007). After the signature of the 1940 treaty, the USSR and Iran called the Caspian Sea a "Shared Sea" (Institute of Mediterranean and Oriental Cultures Polish Academy of Sciences, 2014). Therefore, it can be said that it was the crucial document regarding the legal status of the Caspian basin.

After the dissolution of the USSR, things changed and it became harder to agree on the basis of a unanimous decision about the legal status of the Caspian Sea and its delimitation. Additionally, the newly independent States, which are land-locked States (Land-locked States have no direct access to the high seas), wanted to participate in the natural resources of the basin.

Russia, in the beginning, continued to insist that the above-mentioned treaties were valid. This is because the new States, which created the Commonwealth of Independent States, signed the Alma - Ata Declaration in 1991. In its declaration, it was stated that the members of the Commonwealth are obliged to follow the treaties and agreements of the former USSR (Alma - Ata, 1991), but soon changed its position.

This was the outcome of the new States', and especially Azerbaijan's claims which states that in the case of the USSR's dissolution, the rebus sic stantibus doctrine was applied (Zimnitskaya \& Geldern, 2011). Therefore, this means that the above mentioned treaties are no longer valid because there was a material change. Also, the Caspian Sea should be divided into five riparian States, and every State should be free to make agreements with foreign oil and gas companies. The most important for Russia's policy was to have access to the Caspian Sea and to keep away, as far as possible, any non-riparian State. Hence, that is why, in 1996, it proposed a 45 mile coastal zone for every riparian States. In this zone, every State would have exclusive sovereign rights in the seabed, but the remaining part would be exploited by the five States (Bahgat, 2007). Azerbaijan, Kazakhstan, and Turkmenistan refused to accept it and Russia started to sign bilateral agreements with the littoral States to delimitate the basin.

In this part, it is important to state that in the agreements, the Caspian Sea is not classified either as a sea or a lake. Nevertheless, the participating parties wanted to sign a legal agreement in order to start the exploitation of the natural resources and to enhance the cooperation among them. 


\section{IRAN}

Iran's cornerstone of economy is oil production. Located on the crossroad of religions, sanctions, languages and energy routes, it has acquired survival skills throughout centuries. Iran's oil reserves are estimated to be 400 million barrels, while its gas reserves are estimated as 2 Tcf (EIA, 2015). Despite the fact that Iran does not possess a great abundance of reserves in the region of the Caspian Sea (EIA, 2013), the geographical location of Iran provides it with the capability of functioning as a key player among the landlocked States of the Caspian Sea (Bahgat, 2003). İn other words, the Caspian Sea could be rendered into a convenient and time-saving alternative to the always shifting background Persian Gulf.

It is of utmost importance that an overview of Iran's policy towards the Caspian Sea throughout the years should be given. After the collapse of the Soviet Union, the emergence of newly independent States led Iran to attempt to establish itself as the main agent of the Caspian region (Frappi \& Garibov, 2014). Initially, the Islamic Republic of Iran urged that the Caspian Sea should be purported as res communis, which means that the particular region would be explored and exploited by the littoral States. In other words, the sea would be considered a common heritage of the riparian States (Zimnitskaya \& Geldern, 2010). On the contrary, Iran advocated the need of condominium principle instead of the division of the Caspian Sea in national sectors (Abilov, 2011).

However, Iran's stance was altered in view of the emergence of new interests and stakes in the region (Abilov, 2011). In its attempt to obtain a larger portion of oil revenues, Iran had advocated for Caspian Sea's division in national sectors. What should be pointed out here is the fact that Iran have stressed that the Caspian Sea ought to be divided into five equal parts (Abilov, 2011). Despite the fact that Iran's gas reserves in the Caspian basin reached 2 Tcf, little do they contribute to the nation's total reserves (EIA, 2015). The strategic importance of Iran's particular attitude is threefold. Tehran will try to be established as a "Great Power of a New Great Game" in the region of the Caspian Sea, outbalance the risks in the Persian Gulf and, at the same time, prevent the militarization of the Caspian Sea as well as USA's presence in the region. Iran's stance alteration is compatible with the general alteration in Iran's policy, which tends not to be as adamant as it is in the past decades.

\section{AZERBAIJAN}

Located on the crossroad of Europe and Asia, Azerbaijan is of great geopolitical importance despite its small size (Frappi \& Garibov, 2014). As it can be deduced by the chart below, Azerbaijan has been regarded as a keyrole player in the region of the Caspian Sea since 2006, which was entailed in the foundation of the Azeri-Chirag-Guneshli (ACG) field group between the 
years 2006 and 2008 (EIA, 2013). In addition, their total production in the first half of 2017 reached 585,000 barrels per day (BP, 2017).

Caspian Sea region gross natural gas production (2000-12) trillion cubic feet per year

\section{5}

2.0

1.5

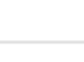




\section{KAZAKHSTAN}

The next littoral State is Kazakhstan, which is a significant global oil and gas producer. According to the world factbook of the Central Intelligence Agency (henceforth CIA), Kazakhstan geographically is a land-locked State in Central Asia, and more specifically, it is the largest land-locked country in the world (CIA, 2017), bordered by Russia, China, Kyrgyzstan, Uzbekistan, Turkmenistan, and the Caspian Sea.

The vast majority of Kazakhstan's deposits is located on the western part of the country, offshore, and onshore of the Caspian Sea. Kazakhstan has four main natural resources' production fields, namely Tengiz field, Karachaganak field, Kurmangazy field, and Kashagan field (Kaiser \& Pulsipher, 2007). Thus, the first two together provides half of the country's production (EIA, 2017). The Kazakh fields are necessary for the State's economy and according to the Ministry of Energy of Kazakhstan, the country, in 2015, exported 79.5 million tonnes of oil and condensate (Government of the Republic of Kazakhstan, 2016). Kazakhstan's main export roots are Italy, China, Netherlands, Russia, and France (Trading Economics, 2017). One of the most important reasons for this is that Kazakhstan tries to have diversified energy markets so as not to depend on Russia.

As we concluded from the above-mentioned, the unsolved legal status of the Caspian Sea affects Kazakhstan too. Kazakhstan, like Azerbaijan, refuses to accept the Soviet- Iranian Treaties of 1921 and 1940 (UN A/52/424, 1997) and leans to believe that the Caspian basin should be classified as a sea and more specifically as an enclosed or semi enclosed sea. Furthermore, the delimitation should be made according to the median line. The utmost important thing of that approach is that the delimitation concerns only the seabed of the Caspian basin and not the surface water. For the surface water, it is believed that the proper solution is the principle of res communis usus of all the riparian States (Shafiyev, 2001).

Kazakhstan, all these years, is stable to this opinion and it made bilateral treaties with Russia, Azerbaijan, and Turkmenistan in order to settle down the tensions and the disputes in the region. In 1998, Kazakhstan and Russia signed an agreement, "On the Delimitation of the Seabed of the Northern Part of the Caspian Sea for the Purpose of Exercising their Sovereign Rights to the Exploitation of its Subsoil", dividing the northern part of the seabed and subsoil by the method of the median line and referring to the common use of the surface waters (UN A/52/983, 1998). Three years later, in 2001, Kazakhstan signed a similar agreement with Azerbaijan. According to Article 1 of the agreement, the States will use the median line to divide the seabed and subsoil of the Caspian basin, but there is no reference to the waters (Agreement between the Republic of Kazakhstan and Azerbaijan Republic on Differentiation of Bottom of the Caspian Sea, 2001). In this part, it should be 
mentioned that these agreements are not an obstacle in case the littoral States decides to achieve consensus on the legal status of the basin.

\section{TURKMENISTAN}

Last but not least, Turkmenistan is also a former Soviet Republic State which holds vast deposits of natural resources. Like the above-mentioned country, Turkmenistan is also a land-locked State, located in Central Asia and bordered by Kazakhstan, Uzbekistan, Afghanistan, Iran, and the Caspian Sea. Since its independence, Turkmenistan became one of the most significant gas producers and is the world's fourth largest exporter of natural gas (Hellenic Shipping News, 2016). Moreover, Turkmenistan is believed to hold huge deposits of natural resources, especially natural gas, which have not been explored yet; hence, it was stated that its potential gas reserves are equal to the ones of Saudi Arabia (Kubicek, 2013).

In 2012, Turkmenistan produced 69 billion cubic meters of natural gas (Safirova, 2015). Also, in 2015, Turkmenistan confirmed his reputation as a leading gas producer, as it produced more than 2.5 Tcf of dry natural gas and exported 1.3 Tcf of natural gas the same year (EIA, 2016). As long as Turkmenistan contains several large natural fields, such as Dauletabad and Shatlyk (Bahgat, 2007), which are located all over its territory among the Caspian Sea, and the exports of the resources are up to $25 \%$ of the State's GDP (CIA, 2017), it is obvious that the paradox of the legal status of the Caspian Sea affects its policy.

Turkmenistan never had a stable position regarding the Caspian Sea, but it changed its position several times since its independence. Initially, in 1996, it supported the 45 mile coastal zone that Russia claimed (Bahgat, 2007). One year later, Turkmenistan wanted the Caspian Sea, both seabed and surface, to be divided (Shafiyev, 2001). In 1997, Turkmenistan's president and the president of Kazakhstan made a joint statement which stated that "Until the Caspian States reach an agreement on the status of the Caspian Sea, the parties will adhere to the delimitation of administrative and territorial borders along a line running through the middle of the Sea" (UN A/52/424, 1997). However, just only a year later, Turkmenistan changed its opinion again and switched to Iran's side. Turkmenistan claimed that the Caspian basin should be divided equally by using the condominium principle and that every State should take $20 \%$ of the region. Moreover, in 1998, the two States in a joint statement claimed that "Until the finalization of the new legal regime, the Treaty on Friendship between Iran and Russia of 1921 and the Agreement on Trade and Shipping between Iran and the Soviet Union of 1940 are the sole international documents governing legal issues relating to the Caspian Sea" (UN A/53/453, 1998). Finally, in 2000, in its letter addressed to the UN secretary General, Turkmenistan was in favor of the division by the sectoral 
approach and stated that the surrounding States should cooperate on a mutual basis (UN A/55/309, 2000).

In this part, it is worth saying that, in 2003, all the five littoral States signed the "Framework Convention for the Protection of the Marine Environment of the Caspian Sea" in order to protect the Caspian basin. According to the Convention, all States should take the appropriate measures and should cooperate with each other in order to prevent, reduce, and control pollution of the Caspian Sea (Framework Convention for the Protection of the Marine Environment of the Caspian Sea, 2003). Although this is a Convention which concern the environment and its protection, it can be said that maybe it is the first step, among all the riparian States, towards a consensus on the legal status of the Caspian basin.

\section{POSSIBLE SCENARIOS}

Despite the fact that the establishment of the legal status of the Caspian basin lies on the determination of the riparian States, it is essential to analyze the possible scenarios. The first scenario includes the Caspian basin being categorized as sea. Supposing that the littoral States have ratified UNCLOS 1982, UNCLOS would regulate the regime of the sea in the Caspian Sea. Under UNCLOS 1982, territorial sea is a term used to describe a belt of sea adjacent to a coastal or archipelagic state where the sovereignty of the coastal or archipelagic state is extended. Each state is entitled to establishing the breadth of its territorial sea (extended to the air space over it and to its bed and subsoil as well) up to 12 nautical miles measured from baselines. Under UNCLOS 1982, all States are entitled to innocent passage through the territorial sea.

The next maritime zone that a coastal State may claim is the Exclusive Economic Zone (hereinafter EEZ). According to UNLCOS 1982, Part V of the Convention, EEZ may be extended until 200nm from the baselines. Therefore, this refers to the rights, jurisdiction, and duties of both coastal and third States. Every coastal States can exercise its sovereign rights for research and exploitation purposes up to 200nm (UNCLOS, 1982).

Prior to the analysis of Continental Shelf, it should be noted that the particular maritime zone is considered to be the second most substantial maritime zone after territorial sea in view of the fact that most natural resources tend to be found in the particular area (Churchill \& Lowe, 1988). According to UNCLOS 1982, Article 77 states that "The coastal State exercises over the continental shelf sovereign rights for the purpose of exploring it and exploiting its natural resources". The rights that the Continental Shelf generates are exclusive; this means that if the coastal State does not explore them or exploit its natural resources, no one may undertake 
these activities without the express consent of the coastal State (UNCLOS, 1982).

It is important to mention here that according to UNCLOS, every country has ipso facto and ab initio its Continental Shelf, but it has to declare its intention to delimit its EEZ. Naturally, a great deal of maritime disputes in the Caspian Sea region is possible to stem from such rule in view of the States' intention to acquire more area to be exploited.

Furthermore, the Caspian Sea would fall into the category of enclosed or semi- enclosed seas. According to Article 122 of UNCLOS 1982, enclosed or semi- enclosed sea is defined as a basin or sea surrounded by two or more States and is connected to another sea or ocean by a narrow outlet. Littoral States surrounding enclosed or semi-enclosed sea are called geographically disadvantaged States. However, it is worth pointing out the fact that a variety of problems and issues are caused primarily by management, conservation and exploration of resources of the sea - either living or not - issues of international navigation as well as pollution issues (Tanaka, 2012). It goes without saying that the matter of resource exploitation is the most prominent.

In case that the Caspian Sea is considered to be a lake, there will be two possible scenarios. A term being particularly stressed in such cases is condominium. Under this notion, the riparian States are entitled to equal sovereign rights (Frappi \& Garibov, 2014). In other words, condominium signalizes the fact that each of the five riparian States would acquire $20 \%$ of the total region of the Caspian Sea. Furthermore, when it comes to the exploitation, resources are administrated jointly by the riparian countries. However, in the case of the Caspian Sea, condominium is not feasible to apply due to the discords that have risen.

On the contrary, according to a second possible scenario, the Caspian Basin may be divided by the use of the median line. In that case, the importance of the equidistance principle should be stressed. However, this scenario would entail in specific States (Iran in particular) acquiring larger share of the basin. Consequently, the riparian States are entitled to exploiting exclusively their national sectors.

\section{CONCLUSION}

Despite what scholar society may advocate, the legal status of the Caspian basin is not about to be established in a short term. The absence of consensus among the riparian States stems from conflicting national interests. The rivalries among the States and the pursuit of each state to establish its order of regulation are bound to continue. However, the bone of contention is not the establishment of the legal status in the basin, but the perpetual question "Who controls the resources?" In other words, the ultimate goal is not to legally define the water of the Caspian Sea, but to define and determine who 
participates in the exploitation of the resources. This can be reflected by the fact that most riparian States of the Caspian Sea have already had companies export oil. In addition, large portion of their economy depends on the revenues from the oil and gas resources. However, what should be borne in mind is whether the particular situation will be led to resolution among the States or it will drive to further rivalries or more ethnic divisions and separatist tendencies.

\section{References:}

1. Abilov, S. (2011). The Legal Status of the Caspian, Hazarraporu.

2. Agreement between the Republic of Kazakhstan and Azerbaijan Republic on differentiation of bottom of the Caspian Sea (2001). Article 1.

3. Bahgat, G. (2003). American Oil Diplomacy in the Persian Gulf and the Caspian Sea, Florida, University Press of Florida.

4. Bahgat, G. (2007). Prospects for energy cooperation in the Caspian Sea, Communist and Post - Communist Studies 40.

5. BP (2017). The Azerbaijan Government and co-venturers sign amended and restated Azeri-Chirag-Deepwater Gunashli PSA, (online available https://www.bp.com/en_az/caspian/press/pressreleases/acg_psa_ame nded.html)

6. Central Intelligence Agency (2017). The World Factbook, Central Asia: Kazakhstan (online available at https://www.cia.gov/library/publications/the-worldfactbook/geos/kz.html)

7. Central Intelligence Agency (2017). The World Factbook, Central Asia: Turkmenistan (online available at https://www.cia.gov/library/publications/the-worldfactbook/geos/tx.html)

8. Churchill, R.R. \& Lowe, A.V. (1988). The Law of the Sea, 2nd edition, Great Britain, Manchester University Press.

9. Framework Convention for the Protection of the Marine Environment of the Caspian Sea (2003). UNEP.

10. Frappi, C. \& Garibov, A. (2014). The Caspian Sea Chessboard. Geopolitical, Geo-strategic and Geo-economic Analysis, Italy, Egea.

11. Ganjaliyev, E. (2011-2012). Building Azerbaijan's Legal Framework for Marine Operations on the basis of UNCLOS, presentation at United Nations - Nippon Foundation Fellow.

12. Gökay, B. (2001). The Politics of Caspian Oil, New York, Palgrave. 
13. U.S Energy Information Administration, (2013), Oil and natural gas in the Caspian Sea region, (online available at https://www.eia.gov/todayinenergy/detail.php?id=12911)

14. Government of the Republic of Kazakhstan (2016). Ministry of Energy of Kazakhstan expects stabilization of oil extraction rate since 2017, (online available at http://ru.government.kz/en/gosupravlenie/1001292-ministry-ofenergy-of-kazakhstan-expects-stabilization-of-oil-output-extractionrate-from-2017.html)

15. Hellenic Shipping News (2016). New Gas Deposits Found in Turkmenistan, (online available at http://www.hellenicshippingnews.com/new-gas-deposits-found-inturkmenistan/)

16. Institute of Mediterranean and Oriental Cultures Polish Academy of Sciences (2014). Hemispheres Studies on Cultures and Societies, Vol. 29, No. 4.

17. Kaiser, M. J. \& Pulsipher, A. G. (2007). A review of the oil and gas sector in Kazakhstan, Energy Policy 35.

18. Kubicek, R. (2013). Energy politics and geopolitical competition in the Caspian Basin, Journal of Eurasian Studies 4.

19. Pawletta, B.J. (2007). The Legal Status of the Caspian Sea, Current Challenges and Prospects for Future Development, Berlin, Springer.

20. Preliminary convention between between Peru and Bolivia concerning a study of the joint utilization of the waters of Lake Titicaca signed at Lima (1955). (available online at http://gis.nacse.org/tfdd/tfdddocs/archiveApril2010/367ENG.html)

21. Safirova, E. (2015). The Mineral Industry of Turkmenistan, 2012 Minerals Yearbook, Turkmenistan.

22. Shafiyev, F.R.O. (2001). The Legal Regime of The Caspian Sea: Views of The Littoral States, Prism Volume: 7 Issue: 6, (online available at https://jamestown.org/program/the-legal-regime-of-the-caspian-seaviews-of-the-littoral-states/)

23. Tanaka, Y. (2012). The International Law of the Sea, Cambridge University Press.

24. The Alma-Ata Declaration (1991).

25. The Constitution of The Azerbaijan Republic (1995).

26. Trading Economics (2017). Kazakhstan Exports, (online available at https://tradingeconomics.com/kazakhstan/exports)

27. Treaty of Friendship between Persia and the Russian Socialist Federal Soviet Republic (1921). Article 1, 11.

28. UN A/52/424 (1997). Position of Kazakhstan on the legal status of the Caspian Sea. 
29. UN A/52/983 (1998). Agreement between the Russian Federation and the Republic of Kazakhstan on the Delimitation of the Seabed of the Northern Part of the Caspian Sea for the Purposes of Exercising Their Sovereign Rights to the Exploitation of its Subsoil.

30. UN A/52/424 (1997). Letter from the Minister for Foreign Affairs of the Republic of Kazakhstan addressed to the Secretary-General.

31. UN A/53/453 (1998). Letter from the Permanent Representatives of the Islamic Republic of Iran and Turkmenistan to the United Nations addressed to the Secretary-General.

32. UN A/55/309 (2000). Letter from the Permanent Representative of Turkmenistan to the United Nations addressed to the SecretaryGeneral.

33. UNCLOS (1982).

34. U.S Energy Information Administration (2015). Iran, (online available at

https://www.eia.gov/beta/international/analysis_includes/countries_lo ng/Iran/iran.pdf)

35. U.S Energy Information Administration (2016). Turkmenistan, (online available at https://www.eia.gov/beta/international/analysis.cfm?iso=TKM)

36. U.S Geological Survey (2010). Assessment of Undiscovered Oil and Gas Resources of the North Caspian Basin, Middle Caspian Basin, North Ustyurt Basin, and South Caspian Basin Provinces, Caspian Sea Area.

37. U.S Energy Information Administration (2013). Overview of oil and natural gas in the Caspian Sea region (online available at https://www.eia.gov/beta/international/regionstopics.cfm?RegionTopicID=CSR)

38. U.S Energy Information Administration (2016). Russia, (online available

at https://www.eia.gov/beta/international/analysis.cfm?iso=RUS)

39. Zimnitskaya, H. \& Geldern, J. (2011). Is the Caspian Sea a sea; and why does it matter?, Journal of Eurasian Studies 2. 